\title{
Quality of life in patients with COPD, depending on the presence of comorbidities
}

\author{
Jakość życia chorych z POChP w zależności od obecności chorób towarzyszących
}

\section{Ewelina Dziedzicc ๑ , Bożena Zboina ${ }^{1}$, Krzysztof Cudzik$^{1}$, Renata Stępień}

\author{
'University of Business and Enterprise in Ostrowiec Świętokrzyski/ \\ Wyższa Szkoła Biznesu i Przedsiębiorczości w Ostrowcu Świętokrzyskim \\ 2Jan Kochanowski University in Kielce/ \\ Uniwersytet Jana Kochanowskiego w Kielcach
}

CORRESPONDING AUTHOR/AUTOR DO KORESPONDENCJI: Ewelina Dziedzic

Wyższa Szkoła Biznesu i Przedsiębiorczości w Ostrowcu Świętokrzyskim ul. Iłżecka 31a, 27-400 Ostrowiec Świętokrzyski e-mail: ewelinadziedzic@cudmed.pl

STRESZCZENIE

Słowa kluczowe:

ABSTRACT

\section{JAKOŚĆ ŻYCIA CHORYCH Z POCHP W ZALĖLNOŚCI OD OBECNOŚCI CHORÓB TOWARZYSZA_CYCH}

Wstęp. Przewlekła obturacyjna choroba płuc (POChP) jest trzecią przyczyną zgonów na świecie wśród chorób przewlekłych. W artykule omówiono związek między jakością życia chorych z POChP, a obecnością chorób towarzyszących głównie nadciśnieniem tętniczym, cukrzycą i hiperlipidemią. Badanie obejmuje subiektywną i holistyczną ocenę stanu zdrowia, co pozwala na dostrzeżenie wszelkich zaburzeń oraz deficytów w funkcjonowaniu chorych z tą jednostką chorobową.

Cel pracy. Celem badań było określenie jakości życia chorych z przewlekłą obturacyjną chorobą płuc w zależności od obecności chorób towarzyszących.

Materiał i metodyka. Grupę badaną stanowiło 319 pacjentów Poradni Chorób Płuc z rozpoznaną przewlekłą obturacyjną chorobą płuc. W badaniach zastosowano metodę sondażu diagnostycznego oraz metodę analizy dokumentacji medycznej. Narzędziem badawczym oceniającym jakość życia pacjentów był kwestionariusz SGRQ (Saint George Hospital Questionaire).

Wyniki. Respondenci, którzy przebyli zawał serca cechowali się nieco niższą jakością życia w domenie „Wpływ na życie” ( $p=0,047)$. Zauważono, że chorzy z nadciśnieniem tętniczym mają niższą jakość życia w domenie „Aktywność" ( $p<0,05)$ i „,Wpływ na życie” $(p<0,001)$. Natomiast $z$ hiperlipidemią niższa jakość życia zauważalna była w subskali „,0bjawy” $(p<0,001)$ oraz „Wpływ na życie” $(p=0,002)$.

Wnioski. Zaostrzenie objawów w przebiegu POChP, przebyty zawał serca, nadciśnienie tętnicze oraz hiperlipidemia, istotnie różnicują jakość życia chorych na POChP. Profilaktyka tych chorób cywilizacyjnych może zapobiec pogorszeniu się jakości życia chorych. przewlekła obturacyjna choroba płuc, choroby towarzyszące, jakość życia

\section{QUALITY OF LIFE IN PATIENTS WITH COPD, DEPENDING ON THE PRESENCE OF COMORBIDITIES}

Introduction. Chronic obstructive pulmonary disease (COPD) is the third leading cause of death in the world among chronic diseases. The article discusses the relationship between the quality of life of patients with COPD and the presence of diseases associated mainly with hypertension, diabetes and hyperlipidemia. The examination includes subjective and holistic assessment of the patient's health condition, which allows to notice any disorders and deficits in the functioning of patients with this disease.

Aim. The aim of the study was to determine the quality of life of patients with chronic obstructive pulmonary disease depending on the comorbidities.

Material and methods. The study included 319 COPD patients treated in the Lung Diseases Clinic with chronic obstructive pulmonary disease. The study was conducted using a diagnostic survey method and analyzing medical records. The research tool assessing patients quality of life was the SGRQ questionnaire (Saint George Hospital Questionaire).

Results. Respondents who had a myocardial infarction had a slightly lower quality of life in the "Impact on life subscale" $(p=0.047)$. It was noted that patients with hypertension had a lower quality of life in the domain of "Activity" $(p<0.05)$ and "Impact on life" $(p<0.001)$. However, with hyperlipidemia, a lower quality of life was noticeable in the "Symptoms" $(p<0.001)$ and "Impact on life" subscale $(p=0.002)$.

Conclusions. Exacerbation of symptoms in the course of chronic obstructive pulmonary disease, a history of myocardial infarction, hypertension and hyperlipidemia are significantly related to the decreased quality of life of patients. Prevention of these civilization diseases can prevent deterioration of the quality of life of patients.

Key words: 


\section{INTRODUCTION}

Chronic obstructive pulmonary disease (COPD) is a progressive disease. As it progresses, patients notice an increase in the severity of the existing disease symptoms as well as an appearance of additional symptoms associated with comorbidities. Systemic inflammation observed in patients with COPD may accelerate the progression of atherosclerosis and contribute to a higher mortality rate of the disease. In advanced stages, in addition to the typical symptoms, including dyspnoea and cough, the disease hinders normal functioning of patients and decreases their quality of life $[1,2]$. Dyspnoea on exertion transforms into dyspnoea at rest, while the residual mucus contributes to exacerbation of the disease, which is associated with the accumulation of bacteria or viruses in the bronchi $[3,4]$. In addition to the common symptoms associated with COPD, patients often have to overcome various comorbidities. They struggle with chronic fatigue, sleep disturbances, as well as fear for their own lives caused by periodic exacerbations of the disease, consequently leading to depression and disability [5,6,7]. Further progression of the symptoms disrupts the patient's day-to-day functioning, resulting in isolation in the professional, social and family spheres $[4,8]$. The complexity of the health condition leads to more frequent occurrence of exacerbations and longer hospitalisation, which requires the treatment of COPD as well as the comorbidities $[5,6,9]$. Hence, examination of the quality of life in such a complex health situation is particularly important, as it includes a subjective and holistic assessment of the condition by the patient, enabling the discovery of any disorders and deficits in the patient's functioning in the fundamental spheres of life [10]. The article discusses the relationship between the quality of life of patients with COPD and the presence of comorbidities, mainly hypertension, diabetes and hyperlipidaemia.

\section{AIM}

The aim of the study was to determine the quality of life of patients with COPD depending on the presence of comorbidities.

\section{MATERIALS AND METHODS}

The study was conducted at the Lung Disease Clinic in Ostrowiec Świętokrzyski during the period between May 2014 and December 2018. The study group consisted of 319 patients diagnosed with moderate to severe COPD according to the Global Initiative for Chronic Obstructive Lung Disease (GOLD). The following criteria were employed for selecting patients for the study: medical diagnosis of COPD and treatment for at least 12 months prior to enrolment in the study, age over 40, informed consent of the patients, lack of cognitive disorders. The exclusion criteria included other clinically significant lung diseases (e.g. asthma, cystic fibrosis, bronchiectasis, lung cancer), cognitive disorders, incorrectly completed SGRQ questionnaire.
The diagnostic survey method and analysis of medical records were conducted in this study. The research tool for assessing the quality of life of patients with COPD was the standardised Saint George's Hospital Questionnaire (SGRQ). The SGRQ included 50 questions on three subscales: S - symptoms, A - activity and I - impact. A specified number of points was assigned to each answer. The sum of the points was the basis for calculating the level of the quality of life. The results for the individual subscales were in the range of $0-100$ points, where zero corresponded to the highest level and 100 indicated the lowest level of quality of life of the examined person [11]. The SGRQ questionnaire is characterised by high reliability, repeatability and effectiveness in the assessment of the quality of life. The smallest significant difference of the questionnaire result was determined at 5.3 points, while the Cronbach's a coefficient for the entire questionnaire was 0.93 [16]. For the purpose of this study, the consent of the author of this questionnaire as well as the consent of the head of the Lung Disease Clinic to conduct the study was obtained. For the analysis of medical records, a medical data collection sheet was used to gather information such as medical records, history of COPD exacerbations in the 12 months prior to the inclusion in the study, history of chronic diseases.

The collected material was statistically analysed using the Statistica statistical package. Statistical analysis was performed with the aid of the Wilcoxon test as well as the Kruskal-Wallis ANOVA test. A 5\% statistical interference error and the related significance level of $\mathrm{p}=0.05$ were assumed, indicating the existence of significant differences.

The consent of the Bioethics Committee at the Jan Kochanowski University in Kielce was obtained for the implementation of the research project (consent no.: 14/2019).

\section{RESULTS}

As many as $77.1 \%(n=246)$ of men and $22.9 \%(n=73)$ of women participated in the study. The respondents were divided into five age groups: up to 60 (13.8\%), 61-65 (27.0\%), 66-70 (27.3\%), 71-75 (18.2\%) and over 76 years of age $(13.8 \%)$. The majority of the patients had vocational education $61.1 \%(n=195)$ and secondary education $20.4 \%$ $(n=65)$. When it comes to $17.6 \%(n=56)$ of patients, they had primary education, while $0.9 \%(n=3)$ had higher education.

More than a half of the respondents, i.e. $58 \%(n=185)$ exhibited no disease exacerbations in the last 12 months. Five COPD comorbidities were identified in the study group (Tab. 1).

\section{Tab. 1. Comorbid diseases in the studied group of patients with COPD}

\begin{tabular}{|l|c|c|c|c|}
\hline \multirow{2}{*}{\multicolumn{1}{|c}{ Comorbidities }} & \multicolumn{2}{c|}{ Yes } & \multicolumn{2}{c|}{ No } \\
\cline { 2 - 5 } & N & $\%$ & N & $\%$ \\
\hline Myocardial Infarction & 55 & 17.2 & 264 & 82.8 \\
\hline Stroke & 19 & 6.0 & 300 & 94.0 \\
\hline Hypertension & 214 & 67.1 & 105 & 32.9 \\
\hline Hiperlipidemia & 182 & 57.1 & 137 & 42.9 \\
\hline Diabetes Mellitus type 2 & 56 & 17.6 & 263 & 82.4 \\
\hline
\end{tabular}


In the 12 months prior to the study, $37.9 \%(n=121)$ of the respondents experienced moderate COPD exacerbation, while severe exacerbation, which was life-threatening and required hospitalisation, was observed in $4.1 \%$ of patients $(n=13)$. Subsequently, an attempt was made to assess the differences between patients with varying degrees of severity of COPD symptoms and the quality of life in the study group. Patients with severe exacerbations were characterised by the lowest quality of life in the „impact on life" $(p<0.001)$ and „overall score” $(p=0.042)$ domains. Conversely, no differences were found in the „activity" domain ( $>0.05)$ (Tab 2).

\section{Tab. 2. COPD exacerbations and overall quality of life assessment}

\begin{tabular}{|l|c|c|c|c|c|c|c|c|}
\hline \multirow{2}{*}{$\begin{array}{l}\text { Quality of life } \\
\text { according to } \\
\text { SGRQ }\end{array}$} & \multicolumn{8}{|c|}{ COPD exacerbations } \\
\cline { 2 - 9 } & \multicolumn{2}{|c|}{ None } & \multicolumn{2}{c|}{ Moderate } & \multicolumn{2}{c|}{ Severe } & \multicolumn{2}{c|}{ Statistics } \\
\cline { 2 - 9 } & SD & M & SD & M & SD & H & p \\
\hline Symptoms (S) & 77.93 & 7.71 & 74.54 & 10.05 & 73.68 & 6.93 & $\mathbf{1 3 . 4 4 0}$ & $\mathbf{0 . 0 0 1}$ \\
\hline Activity (A) & 46.38 & 12.32 & 48.04 & 13.38 & 49.50 & 12.92 & 2.836 & 0.242 \\
\hline $\begin{array}{l}\text { Impact } \\
\text { on life (I) }\end{array}$ & 29.84 & 9.98 & 33.16 & 12.41 & 38.31 & 10.89 & $\mathbf{1 5 . 6 2 6}$ & $<\mathbf{0 . 0 0 1}$ \\
\hline Total (T) & 43.90 & 8.13 & 45.45 & 10.05 & 48.31 & 7.78 & $\mathbf{6 . 3 4 0}$ & $\mathbf{0 . 0 4 2}$ \\
\hline
\end{tabular}

Legend: M- mean, SD- standard deviation, p- significance level, H- Kruskal-Wallis test

Further analysis of the data revealed differentiation between the quality of life and incidence of comorbidities (Tab. 3). It was noted that the history of myocardial infarction differentiated the ,impact on life" domain $(\mathrm{p}=0.047)$. Patients who experienced a heart attack exhibited a slightly lower quality of life in this domain. No differences were found in the remaining areas $(p>0.05)$. It was also noted that patients with hypertension had a lower quality of life in the „activity” $(\mathrm{p}=0.021)$ and „impact on life" ( $\mathrm{p}=0.001)$ domains. The general quality of life of this group of subjects was also noticeably lower $(\mathrm{p}=0.001)$. It is worth emphasising that history of stroke did not affect the quality of life of the subjects $(p>0.05)$. The subsequent stage of the study enabled determination of the statistical significance in the group of patients additionally burdened with the occurrence of hyperlipaemia. This fact differentiated the quality of life in the subscales of "symptoms" $(p<0.001)$ and ,impact on life" $(p=0.002)$. No differences were found in the remaining domains $(p>0.05)$. Another lifestyle disease accompanying patients with COPD was type 2 diabetes, which in our analysis was not statistically significant in relation to the quality of life of patients with COPD ( $>0.05)$.
Tab. 3. Comorbidities and quality of life assessment

\begin{tabular}{|l|c|c|c|c|c|c|}
\hline \multirow{2}{*}{$\begin{array}{c}\text { Quality of life } \\
\text { according to } \\
\text { SGRQ }\end{array}$} & Yes & \multicolumn{2}{c|}{ No } & \multicolumn{2}{c|}{ Statistics } \\
\cline { 2 - 7 } & SD & M & SD & Z & p \\
\hline \multicolumn{7}{|c|}{ Myocardial infarction } \\
\hline Symptoms (S) & 76.53 & 8.42 & 76.45 & 8.89 & -0.324 & 0.746 \\
\hline Activity (A) & 45.34 & 11.71 & 47.51 & 12.95 & -1.419 & 0.156 \\
\hline Impact on life (I) & 31.91 & 11.27 & 29.30 & 10.57 & -1.988 & $\mathbf{0 . 0 4 7}$ \\
\hline Total (T) & 43.01 & 8.30 & 45.03 & 9.05 & -1.772 & 0.076 \\
\hline \multicolumn{7}{|c|}{ Hypertension } \\
\hline Symptoms (S) & 76.04 & 8.96 & 76.67 & 8.73 & -0.641 & 0.522 \\
\hline Activity (A) & 49.53 & 13.43 & 45.97 & 12.27 & -2.302 & $\mathbf{0 . 0 2 1}$ \\
\hline Impact on life (I) & 34.05 & 12.10 & 30.17 & 10.49 & -3.313 & $\mathbf{0 . 0 0 1}$ \\
\hline Total (T) & 46.64 & 9.55 & 43.69 & 8.48 & -3.190 & $\mathbf{0 . 0 0 1}$ \\
\hline \multicolumn{7}{|c|}{ Stroke } \\
\hline Symptoms (S) & 79.01 & 7.17 & 76.30 & 8.88 & -1.475 & 0.140 \\
\hline Activity (A) & 50.17 & 9.86 & 46.95 & 12.90 & -1.678 & 0.093 \\
\hline Impact on life (I) & 31.99 & 11.65 & 31.42 & 11.17 & -0.255 & 0.799 \\
\hline Total (T) & 46.36 & 7.37 & 44.57 & 9.03 & -1.198 & 0.231 \\
\hline \multicolumn{7}{|c|}{ Hiperlipidemia } \\
\hline Symptoms (S) & 78.48 & 6.51 & 73.81 & 10.56 & -4.236 & $<\mathbf{0 . 0 0 1}$ \\
\hline Activity (A) & 46.33 & 12.10 & 48.21 & 13.53 & -1.651 & 0.099 \\
\hline Impact on life (I) & 30.18 & 10.92 & 33.13 & 11.33 & -3.153 & $\mathbf{0 . 0 0 2}$ \\
\hline Total (T) & 44.15 & 8.77 & 45.36 & 9.15 & -1.700 & 0.089 \\
\hline \multicolumn{7}{|c|}{ Diabetes Mellitus } \\
\hline Symptoms (S) & 75.69 & 11.68 & 76.63 & 8.07 & -0.433 & 0.665 \\
\hline Activity (A) & 48.13 & 12.42 & 46.93 & 12.83 & -0.565 & 0.572 \\
\hline Impact on life (I) & 32.99 & 11.69 & 31.13 & 11.06 & -1.402 & 0.161 \\
\hline Total (T) & 45.59 & 8.23 & 44.48 & 9.09 & -0.998 & 0.318 \\
\hline & & & \\
\hline & & & \\
\hline
\end{tabular}

Legend: M- mean, SD- standard deviation, p- significance level, Z-Wilcoxon test

\section{DISCUSSION}

In the present study, both for patients who suffered a myocardial infarction and patients without such a burden, the quality of life is defined as an average. The slightly lower quality of life noted in the area of „impact on life" was probably a result of a change in lifestyle following a heart attack. Hypertension was shown to reduce the quality of life of patients, possibly due to the additional symptoms associated with high blood pressure, such as pain or dizziness during everyday activities (e.g. climbing stairs, carrying groceries). The conducted study demonstrates a lack of statistical significance in the case of stroke history. Thus, it can be assumed then that both patients with a history of stroke and those who never suffered from a stroke experienced similar limitations in everyday life, and their quality of life was average. Another analysed comorbidity was hyperlipidaemia. A statistically significant difference in the "symptoms" subscale evidently demonstrated a lower quality of life in this group of patients. Lipids, which accumulate in the walls of blood vessels, significantly reduce blood circulation. In this case, symptoms of dyspnoea may be more severe. 
Various comorbidities accompany patients with COPD at every stage of the disease. A study conducted by W. Streng et al. on a group of 3499 patients with heart failure demonstrated that as many as $18 \%$ of subjects were diagnosed with COPD. The authors emphasised that regardless of the severity of heart failure, patients with coexisting COPD had a significantly deteriorated quality of life [12]. The „NHANES” studies conducted in 20072012 in the United States as well as in 2007-2015 in Korea revealed differences between the incidence of comorbidities in patients with COPD. The Caucasian race was much more likely to suffer from hyperlipidaemia (65.5\%), while myocardial infarction was much less frequent $(6.2 \%)$. Moreover, stroke (3.6\%) and type 2 diabetes were more frequent $(13.3 \%)$. Slightly more than half of patients with COPD (51.5\%) suffered from hypertension. An interesting relationship was observed in the prevalence of hypertension and hyperlipidaemia in this group of patients, which are two chronic lifestyle diseases [13]. Our investigation involved a much smaller study group; however, a similar correlation was noted. The largest group included patients with hypertension (67.1\%) and hyperlipidaemia (57.1\%). The results of studies conducted by J. Rosińczuk et al. on a group of 100 patients with COPD revealed that the occurrence of comorbidities was associated with deterioration in the quality of life. The results of SGRQ demonstrated a significant reduction in the quality of life in the areas of symptoms, activity and impact on life [14]. A study conducted by L. Rasputin et al. on a group of 272 patients also confirmed that patients with COPD, who were additionally burdened with heart failure, had a significantly lower quality of life compared to a group without such a burden or those with heart failure history only [15].

\section{CONCLUSIONS}

In a group of patients with COPD, the most frequent comorbidities included hypertension and hyperlipidaemia. Exacerbation of symptoms in the course of COPD, history of myocardial infarction, hypertension and hyperlipidaemia significantly differentiate the quality of life in COPD patients. The conducted study revealed the chronic diseases, which most considerably disturb the lives of patients with COPD. The prophylaxis of these lifestyle diseases may prevent the reduction of the patients' quality of life.

\section{Jakość życia chorych z POChP w zależności od obecności chorób towarzyszących}

\section{WSTEP}

Przewlekła obturacyjna choroba płuc (POChP) jest chorobą stale postępującą i wraz z jej progresją chorzy zauważają wzrost nasilenia objawów chorobowych i pojawienie się dodatkowych symptomów związanych chorobami współistniejącymi. Ogólnoustrojowy stan zapalny występujący w przebiegu POChP może przyspieszać postęp miażdżycy tętnic oraz przyczyniać się do wyższego wskaźnika zgonów w tej jednostce chorobowej. Choroba w zaawansowanych stadiach oprócz typowych objawów duszności i kaszlu utrudnia chorym normalne funkcjonowanie i pogarsza jakość życia [1,2]. Duszność wysiłkowa przechodzi w duszność spoczynkową, a zalegająca wydzielina przyczynia się do występowania zaostrzeń choroby związanych z nagromadzeniem się bakterii bądź wirusów w oskrzelach $[3,4]$. Oprócz tych typowych objawów związanych z POChP, chorzy bardzo często muszą się zmierzyć z różnymi schorzeniami. Chorzy borykają się z przewlekłym zmęczeniem, kłopotami ze snem, jak również lękiem o własne życie powodowanym okresowymi zaostrzeniami choroby, w konsekwencji doprowadzając do depresji i inwalidztwa $[5,6,7]$. Dalsza progresja objawów zaburza funkcjonowanie chorego w społeczeństwie doprowadzając do izolacji zawodowej, społecznej i rodzinnej [4,8]. Złożoność sytuacji zdrowotnej prowadzi do częstszego występowania zaostrzeń oraz wydłużenia hospitalizacji, która wymaga nie tylko leczenia POChP, ale również chorób towarzyszących $[5,6,9]$. Stąd badanie jakości życia w tak złożonej sytuacji zdrowotnej, jest szczególnie ważne, gdyż obejmuje subiektywną i holistyczną ocenę stanu przez pacjenta, co pozwala na dostrzeżenie wszelkich zaburzeń oraz deficytów w funkcjonowaniu pacjenta w podstawowych sferach życia [10]. W artykule omówiono związek między jakością życia chorych z POChP, a obecnością chorób towarzyszących głównie nadciśnieniem tętniczym, cukrzycą i hiperlipidemią.

\section{CEL}

Celem badań było określenie jakości życia chorych z POChP w zależności od obecności chorób towarzyszących.

\section{MATERIAŁ I METODYKA}

Badanie przeprowadzono w Poradni Chorób Płuc w Ostrowcu Świętokrzyskim w okresie od maja 2014 roku do grudnia 2018 roku. Grupę badaną stanowiło 319 chorych z rozpoznanym POChP w stadium umiarkowanym do ciężkiego wg GOLD (Global Initiative for Chronic Obstructive Lung Disease). Kryterium doboru chorych do badań stanowiło: rozpoznanie medyczne POChP i leczenie minimum przez 12 miesięcy przed włączeniem do badania, wiek po 40 r.ż., uzyskanie świadomej zgody pacjentów, brak zaburzeń poznawczych. Kryterium wykluczenia stanowiła inna istotna klinicznie choroba płuc (np. astma, mukowiscydoza, rozstrzenia oskrzeli, nowotwór płuc), zaburzenia poznawcze, niepoprawienie wypełniony kwestionariusz SGRQ. 
W badaniach zastosowano metodę sondażu diagnostycznego oraz metodę analizy dokumentacji medycznej. Narzędziem badawczym oceniającym jakość życia chorych na POCHP był standaryzowany kwestionariusz Szpitala Świętego Jerzego (SGRQ - Saint George Hospital Questionaire). SGRQ zawiera 50 pytań w trzech podskalach: Objawy (S - symptoms), Aktywność (A - activity) i Wpływ na życie (I - impact). Do wszystkich odpowiedzi przypisana jest odpowiednia liczba punktów, których suma jest podstawą do obliczenia poziomu jakości życia. Wyniki dla poszczególnych podskali mogą znajdować się w przedziale od 0 do 100 pkt., przy czym zero odpowiada najwyższemu poziomowi , a 100 najniższemu poziomowi jakości życia u badanej osoby [11]. Kwestionariusz SGRQ charakteryzuje się wysoką rzetelnością, powtarzalnością i skutecznością w ocenie jakości życia, a jego najmniejsza istotna różnica wyniku została określona na 5,3 punktów, natomiast współczynnik a Cronbacha dla całego kwestionariusza wyniósł 0,93 [16]. Na potrzebę niniejszego badania uzyskano zgodę autora tego kwestionariusza oraz zgodę kierownika Poradni Chorób Płuc na przeprowadzenie badania. Do analizy dokumentacji medycznej stworzono arkusz gromadzenia danych medycznych takich jak: metryczka, historia zaostrzeń POChP w ciągu ostatnich 12 miesięcy przed włączeniem do badania, historia chorób przewlekłych.

Zebrany materiał poddano analizie statystycznej za pomocą pakietu statystycznego Statistica. Analizę statystyczną przeprowadzono $\mathrm{z}$ wykorzystaniem testu Wilcoxona oraz testu ANOVA rang Kruskala-Wallisa. Przyjęto $5 \%$ błąd wnioskowania i związany $\mathrm{z}$ nim poziom istotności p=0,05, wskazujący na istnienie istotnych różnic.

Uzyskano zgodę Komisji Bioetycznej przy Uniwersytecie Jana Kochanowskiego w Kielcach na realizację projektu badania (zgoda nr: 14/2019).

\section{WYNIKI}

W badaniu brało udział 77,1\% $(n=246)$ mężczyzn oraz $22,9 \%(n=73)$ kobiet. Badanych podzielono na pięć grup wiekowych: do 60 lat $(13,8 \%)$, od 61 do 65 lat $(27,0 \%)$, od 66 do 70 lat $(27,3 \%)$, od 71 do 75 lat $(18,2 \%)$ oraz powyżej 76 lat $(13,8 \%)$. Większość chorych miała wykształcenie zawodowe $61,1 \%(n=195)$ oraz średnie $20,4 \%(n=65)$. Wyksztalcenie podstawowe posiadało $17,6 \%(n=56)$, a wyższe $0,9 \%(n=3)$.

Ponad połowa badanych $58 \%(n=185)$ nie miała zaostrzeń choroby w ciągu ostatnich 12 miesięcy. W badanej grupie wyodrębniono pięć chorób współistniejących z POChP (tab1).

Tab. 1. Choroby współistniejące w badanej grupie pacjentów z POCHP

Tab. 1. Choroby współistniejące w badanej grupie pacjentów z POCHP
\begin{tabular}{|l|c|c|c|c|}
\hline \multirow{2}{*}{ Choroby współistniejące } & \multicolumn{2}{|c|}{ Tak } & \multicolumn{2}{c|}{ Nie } \\
\cline { 2 - 5 } & $\mathbf{N}$ & $\%$ & $\mathbf{N}$ & $\%$ \\
\hline Zawał serca & 55 & 17,2 & 264 & 82,8 \\
\hline Udar mózgu & 19 & 6,0 & 300 & 94,0 \\
\hline Nadciśnienie tętnicze & 214 & 67,1 & 105 & 32,9 \\
\hline Hiperlipidemia & 182 & 57,1 & 137 & 42,9 \\
\hline Cukrzyca & 56 & 17,6 & 263 & 82,4 \\
\hline
\end{tabular}

W ciągu 12 miesięcy przed badaniem umiarkowane zaostrzenie POChP przebyło 37,9\% $(n=121)$ ankietowanych, natomiast ciężkie zaostrzenie, które zagrażało życiu chorego i wymagało hospitalizacji wystąpiło u 4,1\% $(n=13)$. Następnie podjęto próbę oceny różnic między pacjentami o różnym nasileniu objawów POChP, a jakością życia w badanej grupie. Chorzy, którzy mieli zaostrzenia ciężkie charakteryzowali się najniższą jakością życia w zakresie domen „wpływu na życie” $(\mathrm{p}<0,001)$ oraz „wyniku ogólnego” ( $\mathrm{p}=0,042)$. W domenie „aktywność” nie wykazano różnic ( $\mathrm{p}>0,05)$ (tab2).

Tab. 2. Zaostrzenia POChP, a ogólna ocena jakości życia

\begin{tabular}{|l|c|c|c|c|c|c|c|c|}
\hline \multirow{2}{*}{$\begin{array}{c}\text { Jakość życia } \\
\text { wg, SGRQ }\end{array}$} & \multicolumn{7}{|c|}{ Zaostrzenia POChP } \\
\cline { 2 - 9 } & \multicolumn{2}{|c|}{ Brak } & \multicolumn{2}{c|}{ Umiarkowane } & \multicolumn{2}{c|}{ Ciężkie } & \multicolumn{2}{c|}{ Statystyka } \\
\cline { 2 - 9 } & $\mathbf{M}$ & SD & M & SD & M & SD & H & p \\
\hline Objawy (S) & 77,93 & 7,71 & 74,54 & 10,05 & 73,68 & 6,93 & $\mathbf{1 3 , 4 4 0}$ & $\mathbf{0 , 0 0 1}$ \\
\hline Aktywność (A) & 46,38 & 12,32 & 48,04 & 13,38 & 49,50 & 12,92 & 2,836 & 0,242 \\
\hline Wpływ na życie (I) & 29,84 & 9,98 & 33,16 & 12,41 & 38,31 & 10,89 & $\mathbf{1 5 , 6 2 6}$ & $<\mathbf{0 , 0 0 1}$ \\
\hline Wynik ogólny (T) & 43,90 & 8,13 & 45,45 & 10,05 & 48,31 & 7,78 & $\mathbf{6 , 3 4 0}$ & $\mathbf{0 , 0 4 2}$ \\
\hline
\end{tabular}

Legenda: M- średnia, SD- odchylenie standardowe, p- poziom istotności, $\mathrm{H}$ - test Kruskala-Wallisa

W dalszym etapie analizy badań wykazano różnicowanie jakości życia od występowania chorób towarzyszących (tab3). Zauważono, że przebycie zawału serca różnicuje domenę „wpływu na życie” $(\mathrm{p}=0,047)$. Chorzy, którzy przebyli zawał serca cechowali się nieco niższą jakością życia w tej domenie. W pozostałych dziedzinach nie wykazano różnic ( $\mathrm{p}>0,05)$. W badanej grupie zauważono, że chorzy z nadciśnieniem tętniczym mają niższą jakość życia w domenie „aktywność” (p=0,021) i „wpływ na życie" $(\mathrm{p}=0,001)$. Dostrzegalna jest również niższa ogólna jakość życia tej grupy respondentów $(\mathrm{p}=0,001)$. Warte podkreślenia jest to, że przebycie udaru mózgu nie miało wpływu na jakość życia badanych ( $\mathrm{p}>0,05)$. Dalszy etap badań pozwolił na określenie istotności statystycznej w grupie chorych obciążonych dodatkowo występowaniem hiperlipemii. Fakt ten różnicował jakość życia w subskali „objawy” ( $\mathrm{p}<0,001)$ oraz „wpływ na życie” ( $\mathrm{p}=0,002)$. $\mathrm{W}$ pozostałych domenach nie wykazano różnic $(\mathrm{p}>0,05)$. Kolejną chorobą cywilizacyjną towarzyszącą pacjentom z POChP była cukrzyca typu 2, która w niniejszej analizie nie była istotnie statystycznie $\mathrm{w}$ odniesieniu do jakości życia chorych z POChP ( $\mathrm{p}>0,05)$. 
Tab. 3. Choroby towarzyszące, a ocena jakości życia

\begin{tabular}{|c|c|c|c|c|c|c|}
\hline \multirow{2}{*}{$\begin{array}{c}\text { Jakość życia } \\
\text { wg, SGRQ }\end{array}$} & \multicolumn{2}{|c|}{ Tak } & \multicolumn{2}{|c|}{ Nie } & \multicolumn{2}{|c|}{ Statystyka } \\
\hline & M & SD & M & SD & Z & $\mathbf{p}$ \\
\hline \multicolumn{7}{|c|}{ Zawał serca } \\
\hline Objawy (S) & 76,53 & 8,42 & 76,45 & 8,89 & $-0,324$ & 0,746 \\
\hline Aktywność (A) & 45,34 & 11,71 & 47,51 & 12,95 & $-1,419$ & 0,156 \\
\hline Wpływ na życie (I) & 31,91 & 11,27 & 29,30 & 10,57 & $-1,988$ & 0,047 \\
\hline Wynik ogólny (T) & 43,01 & 8,30 & 45,03 & 9,05 & $-1,772$ & 0,076 \\
\hline \multicolumn{7}{|c|}{ Nadciśnienie tętnicze } \\
\hline Objawy (S) & 76,04 & 8,96 & 76,67 & 8,73 & $-0,641$ & 0,522 \\
\hline Aktywność (A) & 49,53 & 13,43 & 45,97 & 12,27 & $-2,302$ & 0,021 \\
\hline Wpływ na życie (I) & 34,05 & 12,10 & 30,17 & 10,49 & $-3,313$ & 0,001 \\
\hline Wynik ogólny (T) & 46,64 & 9,55 & 43,69 & 8,48 & $-3,190$ & 0,001 \\
\hline \multicolumn{7}{|c|}{ Udar mózgu } \\
\hline Objawy (S) & 79,01 & 7,17 & 76,30 & 8,88 & $-1,475$ & 0,140 \\
\hline Aktywność (A) & 50,17 & 9,86 & 46,95 & 12,90 & $-1,678$ & 0,093 \\
\hline Wpływ na życie (I) & 31,99 & 11,65 & 31,42 & 11,17 & $-0,255$ & 0,799 \\
\hline Wynik ogólny (T) & 46,36 & 7,37 & 44,57 & 9,03 & $-1,198$ & 0,231 \\
\hline \multicolumn{7}{|c|}{ Hiperlipidemia } \\
\hline Objawy (S) & 78,48 & 6,51 & 73,81 & 10,56 & $-4,236$ & $<0,001$ \\
\hline Aktywność (A) & 46,33 & 12,10 & 48,21 & 13,53 & $-1,651$ & 0,099 \\
\hline Wpływ na życie (I) & 30,18 & 10,92 & 33,13 & 11,33 & $-3,153$ & 0,002 \\
\hline Wynik ogólny (T) & 44,15 & 8,77 & 45,36 & 9,15 & $-1,700$ & 0,089 \\
\hline \multicolumn{7}{|c|}{ Cukrzyca } \\
\hline Objawy (S) & 75,69 & 11,68 & 76,63 & 8,07 & $-0,433$ & 0,665 \\
\hline Aktywność (A) & 48,13 & 12,42 & 46,93 & 12,83 & $-0,565$ & 0,572 \\
\hline Wpływ na życie (I) & 32,99 & 11,69 & 31,13 & 11,06 & $-1,402$ & 0,161 \\
\hline Wynik ogólny (T) & 45,59 & 8,23 & 44,48 & 9,09 & $-0,998$ & 0,318 \\
\hline
\end{tabular}

Legenda: M- średnia, SD- odchylenie standardowe, p- poziom istotności, Z- test Wilcoxona

\section{DYSKUSJA}

W przedstawionym badaniu jakość życia określana jest jako średnia zarówno u chorych po przebytym zawale serca, jak również bez takiego obciążenia. Zauważalna nieco niższa jakość życia w dziedzinie „wpływ na życie” wynika prawdopodobnie ze zmiany stylu życia po przebytym zawale. Nadciśnienie tętnicze obniżało jakość życia chorych prawdopodobnie poprzez występowanie dodatkowo objawów wysokiego ciśnienia tętniczego takich jak ból, czy zawroty głowy podczas wykonywania czynności życia codziennego (wchodzenie po schodach, noszenie zakupów). Przeprowadzone badanie ukazuje brak istotności statystycznej w przypadku przebycia udaru mózgu. Można więc przypuszczać, że zarówno chorzy z przebytym udarem jak i bez takiego incydentu odczuwają podobne ograniczenia w życiu codziennym i ich jakość życia jest średnia. Kolejną analizowaną chorobą współistniejącą była hiperlipidemia. Istotna statystycznie różnica widoczna w podskali „objawy” wyraźnie prezentuje niższą jakość życia u tej grupy chorych. Lipidy, które odkładają się ścianach naczyń krwionośnych znacznie zmniejszają cyrkulację krwi. Objawy duszności w tym przypadku mogą być bardziej nasilone.
Wielochorobowość towarzyszy chorym na POChP w każdym stadium choroby. Badanie przeprowadzone przez W. Streng i wsp. na grupie 3499 chorych z niewydolnością serca wykazały, że aż $18 \%$ badanych miało rozpoznane POChP. Autorzy podkreślili, że niezależnie od ciężkości niewydolności serca chorzy ze współistniejącym POChP mieli znacznie obniżoną jakość życia [12]. Badania „NHANES” przeprowadzone w latach 2007-2012 w Stanach Zjednoczonych i w Korei w latach 2007-2015, wykazały różnice między występowaniem chorób współistniejących z POChP. Rasa kaukaska znacznie częściej była obciążona hiperlipidemią (65,5\%), zawał mięśnia sercowego występował znacznie rzadziej $(6,2 \%)$, udaru mózgu $(3,6 \%)$, cukrzyca typu 2 występowała częściej (13,3\%). U nieco ponad połowy chorych z POChP (51,5\%) występowało nadciśnienie tętnicze. Ważną obserwacją w tych badaniach było występowanie u tej grupy chorych przede wszystkim nadciśnienia tętniczego i hiperlipidemi, czyli dwóch chorób cywilizacyjnych o charakterze przewlekłym [13]. W naszym badaniu o znacznie mniejszej liczebności grupy badanej zauważyliśmy podobną korelację. Największą grupę stanowili chorzy z nadciśnieniem tętniczym $(67,1 \%)$ i z hiperlipidemią (57,1\%). Wyniki badań przeprowadzonych przez Rosińczuk J. i wsp. na grupie 100 chorych na POChP pokazały, że wraz z wystąpieniem chorób współistniejących pogarsza się jakość życia grupy badanej. Wyniki kwestionariusza SGRQ wykazały znaczne obniżenie jakości życia w dziedzinach symptomów, aktywności i wpływu na życie [14]. Badanie przeprowadzone przez Rasputinę L. i wsp. na grupie 272 chorych także potwierdziły, że chorzy na POChP dodatkowo obciążeni niewydolnością krążenia mają znacznie niższą jakość życia w porównaniu do grupy bez takiego obciążenia lub z samą niewydolnością krążenia [15].

\section{WNIOSKI}

W grupie chorych na POChP najczęściej występującymi chorobami towarzyszącymi były nadciśnienie tętnicze i hiperlipidemia. Zaostrzenie objawów w przebiegu POChP, przebyty zawał serca, nadciśnienie tętnicze oraz hiperlipidemia, istotnie różnicują jakość życia chorych z POChP. Przeprowadzone badanie pozwoliło uwidocznić schorzenia przewlekłe, które najbardziej zaburzają funkcjonowanie chorych na POChP. Profilaktyka tych chorób cywilizacyjnych może zapobiec pogorszeniu się jakości życia chorych.

\section{ORCID}

Ewelina Dziedzic (D) https://orcid.org/0000-0002-0911-6523 Bożena Zboina (iD https://orcid.org/0000-0003-1245-5451 Krzysztof Cudzik (iD https://orcid.org/0000-0002-2352-2210 Renata Stępień (iD https://orcid.org/0000-0002-5882-987 


\section{REFERENCES/PIŚMIENNICTWO}

1. Ulenberg A, Ulenberg G, Felsmann M, i wsp. Edukacja jako istotny aspekt w opiece nad pacjentem z Przewlekłą Obturacyjną Chorobą Płuc (POChP). Journal of Education, Health and Sport. 2017; 7

2. Kupryś-Lipińska I, Kuna P. Impact of chronic obstructive pulmonary disease (COPD) on patient's life and his family. Advances in Respiratory Medicine. 2014: 82; 82-95

3. Janice M, PeiYee T, Mac Aogáin M, et al. The role of acute and chronic respiratory colonization and infections in the pathogenesis of COPD. Respirology. 2017; 22: 634650.

4. Górska K, JankowskiP, Krenke R. POChP w codziennej praktyce klinicznej. Biblioteka Lekarza Praktyka. 2018; 22-24, 40-51.

5. Miravitlles $M$, Ribera A. Understanding the impact of symptoms on the burden of COPD.Respiratory Research. 2017; 18: 67

6. Kessler $R$, Partridge MR, Miravitlles $M$, et al. Symptom variability in patients with severe COPD: a pan-European cross-sectional study. EurRespir J. 2011; 37: 264-272.

7. Dury R. COPD and emotional distress: not always noticed and therefore untreated. Br J Community Nurs. 2016;21:138-141

8. Walentynowicz-Moryl K. Społeczny wymiar zdrowia. Relacje. Studia z nauk społecznych. 2016;1: 71-81

9. Janice M, PeiYee T, Mac Aogáin M. et al.The role of acute and chronic respiratory colonization and infections in the pathogenesis of COPD. Respirology. 2017; 22: 634650.

10. Grochans E, Bąk A, Reczyńska A, i wsp. Czynniki społeczno-demograficzne wpływajace na jakość życia pacjentów z astma i POChP. Family Medicine \& Primary Care Review. 2013; 15(4): 536-539.

11. Kuzniar T, Patkowski J, Libhart J, i wsp. Ocena polskiej wersji St. George's Respiratory Questionnarie u chorych na astmę oskrzelową. Pneumonol. Alergol. Pol. 1999;67: 497-503

12. Streng KW, Nauta JF, Hillege HL. Non-cardiac comorbidities in heart failure with reduced, mid-range and preserved ejection fraction. International Journal of Cardiology. 2018; 71:132-139.

13. Hyun L, Sun Hye S, Seonhye G, et al. Racial differences in comorbidity profile among patients with chronic obstructive pulmonary disease. BMC Medicine. 2018; 16: 178.

14. Rosińczuk J, Przyszlak M, Uchmanowicz I. Sociodemographic and clinical factors affecting the quality of life of patients with chronic obstructive pulmonary disease. International Journal of Chronic Obstructive Pulmonary Disease. 2018; 13: 28692882.

15. Rasputina L, Didenko D, Ovcharuk M. Life quality parameters in patients with combination of stable ischemic heart disease and chronic obstructive pulmonary disease. Wiadomości Lekarskie. 2018;71(8):1560-1565.

16. Kuzniar T, Patkowski J, Libhart J, i wsp. Ocena polskiej wersji St. George's Respiratory Questionnarie u chorych na astmę oskrzelową. Pneumonol. Alergol. Pol. 1999; 67: 497-503.
Manuscript received/Praca zgłoszona do czasopisma: 24.03.2020

Manuscript accepted/Praca zaakceptowana do druku: 24.08.2020

Translation/Tłumaczenie: Agnieszka Svitek, Euro Alphabet 